University of Nebraska - Lincoln

DigitalCommons@University of Nebraska - Lincoln

Faculty Publications, UNL Libraries

Libraries at University of Nebraska-Lincoln

$1-1-1999$

Cataloging Environmental Impact Statements and Related

Documents

Mary K. Bolin

University of Nebraska--Lincoln, mbolin2@unl.edu

Follow this and additional works at: https://digitalcommons.unl.edu/libraryscience

Part of the Library and Information Science Commons

Bolin, Mary K., "Cataloging Environmental Impact Statements and Related Documents" (1999). Faculty Publications, UNL Libraries. 43.

https://digitalcommons.unl.edu/libraryscience/43

This Article is brought to you for free and open access by the Libraries at University of Nebraska-Lincoln at DigitalCommons@University of Nebraska - Lincoln. It has been accepted for inclusion in Faculty Publications, UNL Libraries by an authorized administrator of DigitalCommons@University of Nebraska - Lincoln. 


\title{
Cataloging Environmental Impact Statements and Related Documents
}

\author{
Mary K. Bolin
}

\begin{abstract}
Environmental Impact Statements (EISs) have been published by federal agencies such as the National Marine Fisheries Service, the U.S. Forest Service, the U.S. Geological Survey, and the Environmental Protection Agency, since the 1970s. These government documents can be an important source of environmental information. Some EISs are depository ilems, but most are not. Only a small number of each EIS is printed, and they are not always easy to identify and acquire. Their important content and fugitive nature makes it essential to catalog them to make their existence widely known. This article uses the timber sale EISs published by the Forest Service as examples of the benefits, problems, and techniques of cataloging this material. [Article copies available for a fee from The Haworth Document Delivery Service: 1-800-342-9678. E-mail address: getinfo@haworthpressinc.com <Website: http://www.haworthpressinc.com>]
\end{abstract}

KEYWORDS. Environmental impact statements, forest service, cataloging, grey literature

\section{INTRODUCTION}

Discussion on the bibliographic control and processing of government documents has generally centered on U.S. Government Printing Office (GPO) depository documents and on the needs of depository

Mary K. Bolin is Head, Technical Services, and Associate Professor, University of Idaho Library, Moscow, ID 83844-2350.

The author may be reached at: mbolin@uidaho.edumail and http://www.uidaho. edu/ mbolin/.

Resource Sharing \& Information Networks, Vol. 14(1) 1999

(C) 1999 by The Haworth Press, Inc. All rights reserved. 
libraries. The volume of depository documents has made local cataloging generally impractical. Many libraries have opted for loading a separate GPO database, or for loading bibliographic records of GPO items into their online catalogs. The literature on government documents includes many articles on the considerations involved in bibliographic control of documents. ${ }^{1}$

The government creates numerous documents, including many Environmental Impact Statements (EISs), that are not distributed by the GPO through the depository program. Whereas a depository library receives government publications from a core of prominent government agencies, the non-depository documents that a library collects may represent a particular regional or subject interest.

EISs published by such agencies as the National Marine Fisheries Service, the U.S. Forest Service, the U.S. Geological Survey, and the Environmental Protection Agency can be an important source of environmental information. Some are depository items, but most are not. Only a small number of each EIS is printed, and they are not always easy to identify and acquire. Their important content and fugitive nature makes it essential to catalog them. Cataloging them makes them available locally, and, through library networks, to larger audiences. This article uses the timber sale EISs published by the Forest Service as examples of the benefits, problems, and techniques of cataloging this material.

\section{NATIONAL ENVIRONMENTAL POLICY ACT}

The National Environmental Policy Act (NEPA) of 1969 required federal agencies to prepare analyses of the environmental impact of significant proposed federal decisions. These significant decisions include whether to sell timber from federal land, whether to build a dam or other structure at a given location, and so on. These analyses are prepared with input from members of the public and from agencies and organizations with an interest in the proposed action. In 1978, the Council on Environmental Quality issued final regulations for implementing NEPA. Most NEPA documents date from after $1978 .^{2}$

Since the EIS itself is just one of the documents that an agency might produce when complying with NEPA, "NEPA document(s)" will be used from this point forward to refer to these documents in general. "EIS" will be used to refer only to the Environmental Impact Statement itself.

\section{NEPA'S IMPACT}

A recent assessment of the impact and effectiveness of NEPA states that:

NEPA was the crucial first step toward a comprehensive national policy integrating environmental, economic, and social concerns. With the passage of NEPA, agencies began to take a hard look at the environmental consequences of their actions before they made a final decision. They began to consult with the public on what they were proposing to do, accept public views on their proposals, and respond to those views. NEPA also called for agencies to consult with state, local, and tribal governments concerning their plans, and provided agencies with a mechanism to coordinate overlapping jurisdictional responsibilities. ... NEPA's most enduring legacy is a framework for collaboration between federal agencies and those who will bear the environmental, social, and economic impacts of their decisions. ${ }^{3}$

The documents resulting from compliance with NEPA thus constitute an important source of environmental and public policy information, particularly in Alaska and other western states with large proportions of public land, numerous dam projects, national forests, etc..

\section{OTHER SIMILAR DOCUMENTS}

NEPA documents are a class of technical reports. They share these characteristics of technical report literature: they are disseminated to a limited audience, arc not subjected to peer review, and are the report of ongoing research. These characteristics make them elusive and ephemeral and add to their value for libraries in regions that have a collection emphasis in subject areas such as forestry, water resources, power and navigation, and other areas where federal decisions have significant impacts. Moreover, since most are not depository items, they must be cataloged for users to know that they are available in the library.

NEPA documents are important to researchers in land use planning, forest resources, forest ecology, and wildlife as well as to those interested in the history, geology, and geography of a region. When they are cataloged, they can be retrieved along with other items about the 
particular region and other items on the particular topic of the document (such as timber sales, nuclear reactors, etc.). ${ }^{4}$

\section{BIBLIOGRAPHIC CONTROL}

The Federal Register contains information about many NEPA documents as they are published. Several indexes are available, including the monthly EIS: Digests of Environmental Impact Statements and its yearly cumulation. Indexes such as Environment Abstracts and others have citations for some NEPA documents. ${ }^{5}$

Acquiring NEPA documents, however, is a labor-intensive effort. It is not possible to contact an agency and ask that all copies of all NEPA documents be sent to a library. Rather, the librarian must identify and request each document as it is created. These documents are by definition rare, since only twenty to one hundred copies of each one might be printed. It has been known to happen that an agency has contacted a library to get back a copy of a NEPA document that a library has preserved but that the agency has not.

While the tools mentioned earlier are valuable for identifying NEPA documents and for gaining some access to their contents through abstracts, the library catalog continues to be valuable for identifying and locating the NEPA documents that a library owns and for integrating those documents with other environmental literature in the library. Moreover, adding records for these materials to the bibliographic databases of cataloging utilities effectively notifies the world of the existence of these valuable documents.

\section{FOREST SERVICE RESPONSE TO NEPA REQUIREMENTS}

The Forest Service is one of the agencies that have felt the impact of NEPA requirements the most. Its NEPA process involves significant public input through "scoping"--seeking reactions from the public and from other agencies. Therefore, it is not only valuable to catalog these items and make users aware of their existence, it is also useful to examine NEPA documents from the Forest Service as an example of how agencies respond.

An early evaluation of NEPA states: [t]here appears to be a corrclation between the active, wellstaffed NEPA agencies and the use of outreach techniques to increase citizen involvement. The outstanding examples were the Forest Service and the Corps of Engineers ... The Forest Service has allowed a remarkable degree of citizen involvement in its prescoping, daily conduct of its work. ${ }^{6}$

The Forest Service is seen as having reduced delay in the NEPA process by, among other things, the "[u]se of environmental assessments; use of scoping; combining environmental documents with other documents." 7

By 1981, shortly after the final NEPA regulations had been issued, resource management NEPA documents from the Forest Service totaled 8,481 Environmental Assessments and sixty-one Environmental Impact Statements ${ }^{8}$ as well as forty-two records of decision through the end of $1980 .{ }^{9}$ Thousands more have appeared in the intervening years.

\section{TIMBER SALE DOCUMENTS}

NEPA "requires federal agencies to prepare a 'detailed statement' for proposed major actions that significantly affect the quality of the human environment. The statement must include the environmental impacts of the proposed action and any adverse environmental impacts that cannot be avoided should the proposal be implemented. ${ }^{10}$ Often, these NEPA documents may be the only things ever written about some place or project of environmental significance.

NEPA compliance is a decision-tree with a number of branches for the agency to follow. Some types of decisions have been given "categorical exclusions" from the NEPA process. These include administrative functions of an agency or activities that fall below a certain threshold. ${ }^{11}$ An environmental assessment $(\mathrm{E} \Lambda$ ) is made for decisions that do not have a categorical exclusion; the result of the EA is a Decision Notice or Record of Decision (ROD) with either a finding of no significant impact (FONSI) or the need for an EIS. 12 "Scoping"inviting input from other agencies and the public-follows the decision to prepare an EIS. ${ }^{13}$

Actions that require EAs include:

upgrading a road from dirt to gravel and timber management (including timber sales). In an environmental assessment on a 
timber sale, the document would cover the whole cycle of building roads to the cutting area, the cutting operations, and reforesting. Other examples of environmental assessment involve mining permits and preparation of a recreational development, such as a campground. ${ }^{14}$

The Forest Service publishes an EA, ROD, and possibly an EIS for proposed timber sales to be held within the national forests. The ROD and EIS are written by staff at individual ranger districts within the national forests. Each timber sale may therefore have several documents associated with it: the Draft EA, the Final EA, the ROD/FONSI, and possibly the draft and final EIS. These publications have standard formats. The EAs and EISs are usually more traditional publications with bound pages, covcr, and title page. In contrast, the ROD/FONSI is more like a conventional business letter that consists of a relatively small number of pages of "typescript" with no covers or title page.

The ROD/FONSI is published prior to a proposed timber sale and is disseminated along with the EA so that those interested may comment on the views expressed during the scoping process. The result of the scoping process helps determine whether an EIS will be issued.

\section{DETERMINING BIBLIOGRAPHIC IDENTITY}

The first question for the cataloger is how many separate titles are associated with each timber sale. Cataloging one item in isolation might lead to a different decision than the experience of cataloging many NEPA documents over time. Important terms for the cataloger include:
Term

Abbreviation

Comments

Environmental

EA

Assessment

Record

ROD of Decision
Finding of No HONSI

Significant

Impact

Environmental

Impact Statement

EIS

\begin{abstract}
Indicates that EIS is not required. Often issued as part of ROD
\end{abstract}

Written if proposed decision has significant environmental impact; often draft and final versions ${ }^{15}$
Cataloging the ROD separately accurately reflects the nature of the NEPA process. The ROD and EA are sometimes received together. The ROD, often a few pages stapled together, may arrive in an envelope on top of the EA, beneath it, or between the pages of the EA. The brevity, lack of publishing features such as a cover, and the similarity in title and contents between the ROD and the EA might lead the cataloger to view it as part of the EA and to treat it as accompanying material or something similar. However, each item should be treated as a separate title. One reason for this is that the items may not all be received at the same time. Another is that the dates of publication are often different. The different dates are a reflection of the fact that the process of producing NEPA documents consists of several steps and several successive publications; the ROD and EA are a reflection of that process.

\section{RECORD OF DECISION}

For a cataloger dealing with one of these items, the first problem is the chief source of information. Like a typical business letter, the ROD/FONSI generally lacks a title page or cover. The title is most often the caption above the first page of text. It is generally formatted as three or more lines of unpunctuated type, e.g., "Decision Notice and Finding of No Significant Impact/Sheep Creek Timber Sale/St. Maries Ranger District/Idaho County Idaho." Some RODs add "USDA Forest Service" or a further elaboration of the corporate body. The date is rarely found here. It is generally found at the end of the document where the signature of the district ranger and other persons responsible for the ROD are found.

Title main entry should be used because, while there are persons associated with the ROD, the authorship is diffuse and uncertain and does not meet the criteria described in $A A C R 2^{16} 21.1 \mathrm{~A} 2$ for works by a 
single author. The title consists of the words "Decision Notice and Finding of No Significant Impact, [Name of Timber Sale]." The formulaic nature of the first part of the title makes it better to treat it and the name of the timber sale together as title proper rather than tagging the timber sale name as other title information. The name of the ranger district could be included as other title information in the title field; however, this is better treated as a statement of authorship and/or publication.

The place of publication is sometimes included with the caption information. Otherwise, it is generally available from the signature information at the back of the ROD. The ranger district has a hierarchical relationship to the national forest, the Forest Service, and its parent agency the U.S. Department of Agriculture. The names further up in the hierarchy sometimes appear, but the publisher of the ROD is certainly the ranger district. The source of date of publication is generally the date on the signature page that appears as a colophon. It can generally be assumed to accurately reflect the year in which the item was issued, but generally appears in brackets because of its source and format.

\section{AUTHORSHIP}

The question of authorship is an interesting one. The names of the people who wrote the ROD are not prominent on the item and almost never appear on the caption that is most often used as the chief source of information. The district ranger and others above him or her in the Forest Service hierarchy appear with their signatures at the back of the ROD. While this indicates their knowledge and approval of the content of the text, it is not a clear indication of authorship by one or more persons as stated in $A A C R 2 R 21.1 \mathrm{~A} 2$. The presence of the name of the ranger district and other corporate units after the title can be taken as an indication of authorship and might argue for transcribing that information in a statement of responsibility.

The NEPA documents that are cataloged by the Library of Congress (LC) or GPO very often have corporate main entry. Presumably, LC is applying $A A C R 2$ rule $21.1 \mathrm{~B} 2 \mathrm{c}$ : entering a work that "record[s] the collective thought of the body (. . . official statements of position on external policies)."17 Most other libraries have not found the case for corporate main entry strong enough in these documents, and they are more often cataloged with title main entry and an added entry for the forest or ranger district that issued the document. The corporate body that LC generally chooses as author ranges from none at all to "United States. Forest Service" to the ranger district. The ranger district, or national forest if no ranger district is named, is the appropriate corporate body, however; and this is confirmed by the statement by one source that, "[ $t$ ]he environmental assessment is a highly judgmental [sic] affair in the Forest Service, left to the discretion of the Ranger in the field or the Forest Supervisor in some cases."18

\section{OTHER DESCRIPTIVE ELEMENTS}

The ROD is often unpaged, leading to " $1 \mathrm{v}$. (unpaged)" or "[12] p." The ROD may be illustrated by maps of the area, but frequently a separate folded map is included and is described as accompanying material. The notes area will nearly always have "Caption title," and notes on the source of the date, e.g., "May 5, 1982-p. [4]." Parts of the title area that are not transcribed as other title information, statement of responsibility, or publisher information could also be given in a note.

While the name of the ranger district and other corporate bodies might or might not appear in a statement of responsibility, the ranger district is responsible for the contents of the ROD and should certainly be given as a corporate name added entry. While other corporate names may appear prominently, such as those of the national forest and of the Forest Scrvice itself, it is redundant and therefore generally inappropriate to make added entries for these names. The district ranger is the person most unambiguously responsible for the contents of the document and therefore could be given a personal name added entry as well.

The cataloging examples included here are taken from the WLN database and reflect variations in descriptive and subject cataloging.

Figure 1 is an example of a ROD/FONSI showing WLN-style MARC tagging.

\section{EIS AND ENVIRONMENTAL ASSESSMENT}

The $\mathrm{E} \Lambda$ is a longer, more complex and detailed publication that describes the environment of the timber sale area as background for the ROD. There is often a draft assessment that is later followed by a final assessment. 
FIGURE 1. ROD/FONSI for EA: Chief Source (caption title)

Decision Notice and Finding of No Signifizant Impact

Pelke West Branch Proposed Timber Sale

Environmental Assessment, Bonner County, Idaho USDA - Forest Service

Idaho Panhandile National Forests Priest Lake Ranger District

043 a |n-us-id0860 |a $\quad \mid$ A 13.2:P41 $24500 \quad$ ab $\quad$ Decision notice and finding of no significant impact:|Pelke West Branch propased timber sale environmental assessment Bonner County, Idaho.

260 labc |[Priest River, Idaho] : USDA - Forest Service, Idaho Parhandle National Forests, 260 labe [Priest River, Idaho] :
Priest Lake Ranger District, [1986?]

300 labc $\mid 1 \mathrm{v}$. (various pagings) : maps $; 28 \mathrm{~cm}$

500 la Caption title.

650-0 |axzz |Logeing|Environmental aspects|[daho|Bontler County.

$651-0$ la Idaho Panhandle National Forests

7101 labb United States.Forest Service.Priest Lake Ranger District.

7008 DATE KY $=$ DATE1 $=1986 \mathrm{DATE2}=$ PLACE- $\mathrm{idu}$ LAN= $=$ -

AUDI $=\quad$ FORM $=$ CONTENTS $=\quad$ GOV $\mathrm{PUB}=\mathrm{f}$ CONF $=0$ FEST $=$

$0 \quad \mathrm{NDEX}=0 \quad \mathrm{FIC}=0$

$B 1 O G=$ MOD REC $=\quad$ CAT S $=\mathrm{d}$ RULES $=$ a CTL $\mathrm{TYP}=$

\section{An assessment of NEPA states:}

the role of the EA has evolved to the point where it is the predominant way agencies conduct NEPA analyses. Conceived as a brief analysis to determine the significance of environmental effects, the EA increasingly includes mitigation measures that reduce adverse effects below significant levels. ${ }^{19}$

As one would expect:

many more EAs are written than EISs . . A Annual EIS numbers include draft, revised, supplemental, and final EIS documents for single projects, while EAs are often not reported at all. . . The annual number of draft, revised, final, and supplemental, and final EISs prepared has declined from approximately 2,000 in 1973 to 608 in 1997, averaging 508 annually between 1990-1995.20

While NEPA regulations describe discrete publications that are the result of a linear decision process, this is not always the case. As agencies accumulate more experience, different practices have been devised. "Mitigated FONSIs" are one such practice:

agencies increasingly identifying and proposing measures to mitigate adverse effects of proposed actions during the preparation of EAs. While preparing EAs, agencies often discover impacts that are "significant," that would require preparation of an EIS. Agencies may then propose measure to mitigate those environmental effects. If an agency finds that such mitigation will prevent a project from having significant impacts on the environment, the agency can then conclude the NEPA process by issuing a FONSI, rather than preparing an EIS. The result is a 'mitigated FONSI. 21

\section{DESCRIPTION OF EA AND EIS}

The EA and subsequent EIS, unlike the ROD, are generally professionally printed and bound and have cover, title page, and other conventional bibliographic apparatus. The title and publication information appear on both the title page and the cover. These are often slightly different and require a "cover title: ..." note and title added entry.

Like the ROD, the EA and EIS do not have personal authorship but are presented as a work emanating from a corporate body. The name of the Forest Service and/or one of its subdivisions appears on the cover and also on the title page, generally in the area in which the publisher appears, not in the area associated with an author.

ROD/FONSI, EA, and EIS will need an 006 field to describe accompanying maps; and these publications always require an 043 field indicating the geographic area.

Figures 2-3 are examples of cataloging records for draft and final EA.

Figures 4-5 are records for draft and final EIS.

The EA is actually the first step in the NEPA process. If no significant impact will result from the decision, the EA and the "Decision Notice and Finding of No Significant Impact" (ROD/FONSI) are the only NEPA documents associated with that decision. If a significant impact is anticipated, then an EIS is published. For this reason, the ROD is sometimes incorporated with the EIS.

Figure 6 is a record for ROD done in conjunction with an EIS.

Figure 7 is an example of an EIS and ROD cataloged as a multipart item.

\section{SUBJECT CATALOGING}

Libraries may choose to class these publications with other materials on forest resources, land use, and so on and to integrate them into 
FIGURE 2. DRAFT EA: Chief Source (caption title)-Personal Authors

Draft Environmental Assessment: Big Creek Timber Sale and Analysis Area Clearwater National Fores Powell Ranger District Idaho County, Idaho Responsibie Official: James C, Bate Prepared By Janet Kurman And Bob Leighty.

043 la |n-us-id0860 a |A 13.92:C58x/Big Creek/Draft24500 labc Draft environmental assessment: :Big Creek timber sale and analysis area, Clearwater National Forest, Powell Ranger District, Idaho County, Idaho /responsible official: James C. Bates ; prepared by Janet Kurman and Bob Leighty.

260 abc [[Orofino, Idaho]: The Forest, [1985?]

300 abo $11 \mathrm{v}$ ( (uarious pagings) |maps $\mid 28 \mathrm{~cm}$

500 la Caption title.

650-0 |axzz Logging|Environmental aspects|Idaho|Clearwater National Forest.

651-0 la Clearwater National Forest (Idaho)

7001 a |Bates, James C.

7001 la Kurman, Janet.

7001 a

7101 abb |United States,|Forest Service.|Powell Ranger District.

008 DATE $K Y=s$ DATE $1=1986 \mathrm{DATE} 2=\quad$ PLACE $=$ idu LAN $=$ engLLUS $=\mathbf{b}$

AUDI $=\quad$ FORM $=\quad$ CONTENTS $=\quad$ GOV PUB $=f \quad C O N F=0 \quad$ FEST $=$

TYP=

$\mathrm{NDEXX}=0 \quad \mathrm{FIC}=0 \quad \mathrm{BIOG}=\mathrm{MOD} \mathrm{REC}=\mathrm{CATS}=\mathrm{d} \quad \mathrm{RULES}=\mathrm{a} \mathrm{CTL}$

their regular collection. These U.S. documents can also be classed with a Superintendent of Documents call number that reflects the issuing agency. Forest Service documents call numbers begin with the " $A$ " that represents the Department of Agriculture and continue with numbers for the Forest Service, the national forest involved, and so on. Subject headings for this material reflect the geographical area involved and the general environmental area being assessed, e.g., "Land use-Idaho-Idaho County." "Timber sales" or "Logging" with a geographical subdivision and the general subdivision "Environmental aspects" are also appropriate headings. The general headings "Forest reserves" and "Forest resources" are often found on records for these materials along with geographic subdivisions. ${ }^{22}$

It is common to find the heading "Environmental assessment" applied to environmental impact statements, but this is not an appropriate heading. Environmental assessment is not the subject of these works, nor is it a form subdivision such as "Periodicals," but a description of their contents. "Environmental assessment" is applied
FIGURE 3. FINAL EA: Chief Source (caption title)-Personal Authors

Final Environmental Assessment: Big Creek Timber Sale and Analysis Area Clearwater National Forest Powell Ranger District

Idaho County, Idaho

Responsible Official: James C. Bates

Prepared By Janet Kurman And Bob Leighty.

043 a |n |n-us-id0860 la |A 13.92:C58x/Big Creek/Environ. Assess.24500 abo Final environmental assessment :Big Creek timber sale and analysis area, Clearwater National Forest, Powell Ranger District, Idaho County, Idaho//responsible officiali: James C. Bates ; prepared by Janet Kurman and Bob Leighty.

260 abc |[Orofino, Idaho]:|The District, [1985?]

300 jabc |1 $\mathrm{v}$. (vatious pagings): |maps; $; 28 \mathrm{~cm}$

500 a Caption title.

650-0 axzz Logging|Environmental aspects|Idaho|Clearwater National Forest.

7001 a Bates, James C.

7001 Ja Kurman, Janet

7001 la Leighty, Bob.

7101 labb United States.|Forest Service.|Powell Ranger District.

008 DATE KY $=s$ DATE $1=1986$ DATE2 $=$ PLACE $=$ idu LAN $=$ englLLUS $=b$ $\mathrm{ALDI}=\quad \mathrm{FORM}=\quad \mathrm{CONTENTS}=\quad$ GOV $\mathrm{PUB}=\mathrm{f}$ CONF $=0 \quad \mathrm{FEST}=$

$0 \quad \mathrm{NDEX}=0 \quad \mathrm{FIC}=0$

$\mathrm{BIOG}=\mathrm{MOD}$ REC $=$ CAT $\mathrm{S}=\mathrm{d}$ RULES $=$ a $\mathrm{CTL}$ TYP $=$

\section{FIGURE 4. DRAFT EIS: Chief Source: (title page)}

Boulder and Wyman Gulch Vegetation Maragement

(Timber Sale and Prescribed Burning) Draft Environmental Impact Statement Beaverhead-Deerlodge National Forests

043 la n-us $-\mathrm{mt}$

$$
\text { Philipsburg Ranger District. }
$$

24500 labc Boulder and Wyman Gulch vegetation management (Timber

sale and prescribed burning) : draft environmental impact statement / Beaverhead-Deerlodge National Forests, Philipsburg Ranger District.

260 abc |Philipsburg, MT :|Philipsburg Ranger District, |[1996]

300 labc $\mid 1 \mathrm{v}$. (various pagings) :|jill, maps ; $\mid 28 \mathrm{~cm}$.

504 a |Includes bibliographical references.

500 |a |"Match 1996."

650-0 |axzz |Logging|Environmental aspectși|Montana|Deerlodge National Forest.

650-0 |axzz |Logging Envirommental aspects|Montana|Beaverhead National Forest.

650-0 |azz |Forest management|Montana|Deerlodge National Forest.

650-0 azz Forest management|Montana|Beaverhead National Forest.

710 labb Juited States. Forest Service. Philipsburg Ranger District.

008 DATE $K Y=s$ DATE $I=1996 \mathrm{DATE} 2=\quad$ PLACE $=$ mtu LAN $=$ engLLUS $=$
AUDI $=\quad$ FORM $=$
CONTENTS= GOV PUB $=\mathrm{f} \quad \mathrm{CONF}=0$ TYP $=$ 
FIGURE 5. FINAL EIS: Chief Source (title page)

Final Environmental Impact Statement: Hungry-Mill Tinber Sales.Grangeville,Idaho Clearwater Ranger DistrictNezperce National Forest

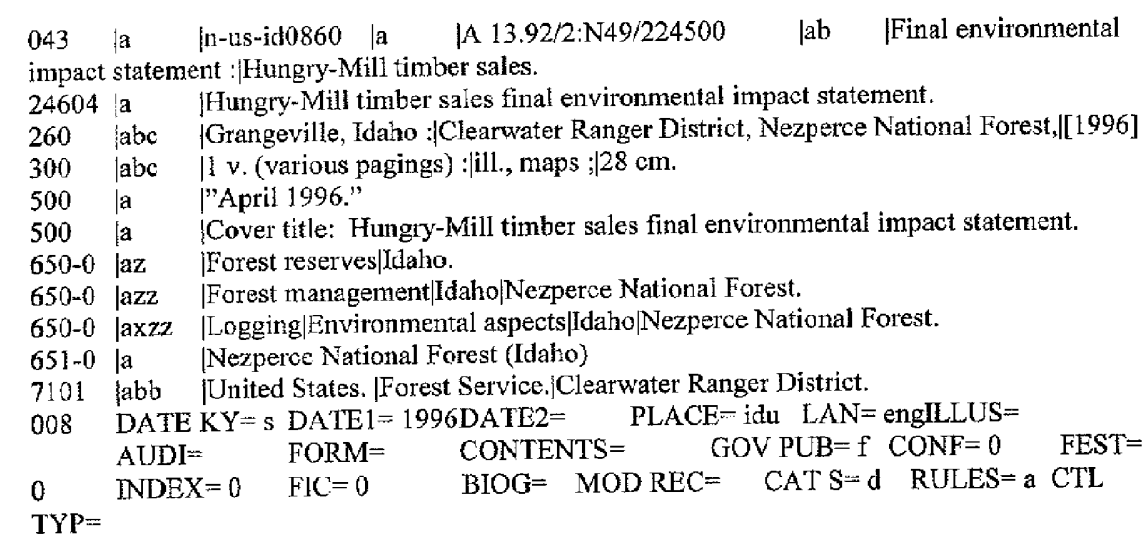

\section{FIGURE 6. FINAL EIS with ROD: Chief Source (title page)}

Hungry-Mill Timber Sales Final Environmental Impact Statement Record of DecisionGrangeville, Idaho

Clearwater Ranger DistrictNezperce National Forest

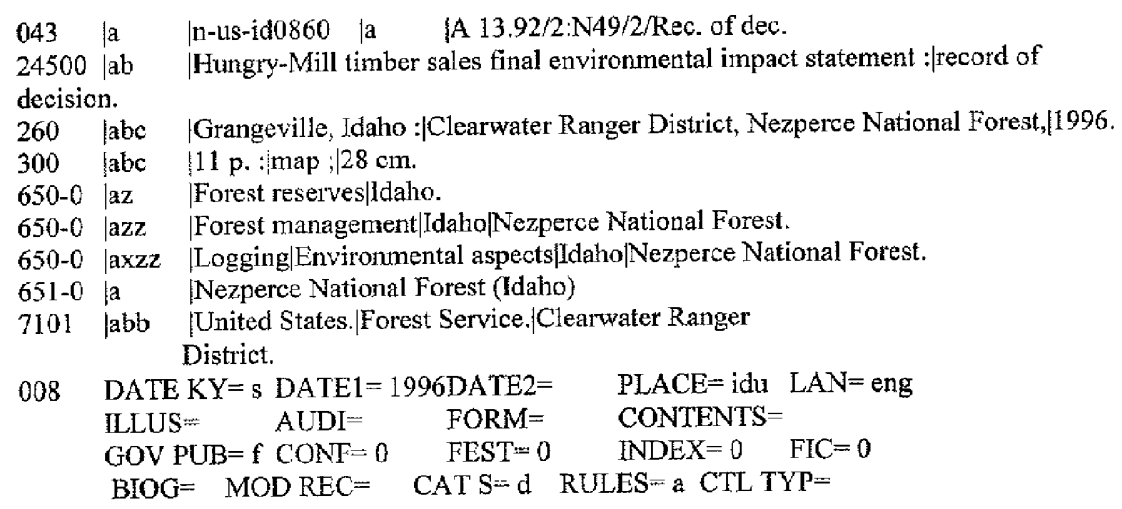

to works that deal with techniques, methods, problems, etc., involved in doing environmental assessment.

The geographic subdivisions indicate the state and county or national forest. If the name of the forest does not appear as a geographic subdivision of a topical subject heading, it should be traced as a geographical subject heading because the national forest is the basic
FIGURE 7. EIS with ROD; Chief Source (cover title)-Done as Multiple Volumes

Northwest Baranof Timber Sales

Final Environmental impact statement

United States Department of Agriculture Forest Service

Tongass National Forest

\section{3 la |in-us-ak}

090 lab ISD428.T6|N67 199624500 jabc Northwest Baranof timber sales ifinal environmental impact statement/United States Department of Agriculture, Forest Service, Tongass National Forest.260 labc |Sitka, Alaska :USDA Forest Service, Alaska Region, Tongass National Forest, Chatham Area, [1996]

300 |abc 13 v. : ill., maps; $28 \mathrm{~cm}$.

440-0 av R10-MB;310a-c

500 la Cover title.

500 la |"February 1996".

500 fit |Emprint from: Summary and record of decision.

500 la Includes 6 folded sheets of maps.

504 la Includes bibliographical references and index.

5050 a Volume I-Volume II-Summary and record of decision.

650-0 lakzz [Logging'Environmental aspects!Alaska|Tongass National Forest.

7102 a Tongass National Forest (Alaska)

006 FORM MAT $=$ e BASE MAP $=$ FORMAT $=$ CART TY $=$

RELIEF $=\quad$ INDEX $=0$ GOV PUB $=f$

008 DATE KY $-\mathrm{s}$ DATE $1=1996 \mathrm{DATE} 2=\quad$ PLACE $=$ aku LAN $=\mathrm{eng}$ ILLUS $=\mathrm{ab} \quad \mathrm{AUDI}=\quad$ FORM $=$ CONTENTS $=$ GOV PUB $=\mathrm{f}$ CONF $=0 \quad \mathrm{FEST}=0 \quad$ INDEX $=0 \quad$ FIC $=0$ $\mathrm{BIOG}=\mathrm{MOD} \mathrm{REC}=\quad \mathrm{CATS}=\mathrm{d}$ RULES $=\mathrm{a}$ CTL TYP $=$

subdivision of the Forest Service. Unlike ranger districts, the national forest is not subject to frequent reorganizations; and tracing its name as a subject is useful for collocating documents from one area.

\section{NAME AUTHORITY}

Name authority for the many corporate bodies involved in the production of NEPA documents is obviously a crucial aspect of cataloging these itcms. The bodies most frequently responsible for the ROD are the ranger districts that are part of the national forests. While the ranger districts are associated with the national forests in which they reside, the names are established as a subdivision of the Forest Service, e.g., "United States. Forest Service. Powell Ranger District." These are Type 1 corporate bodies as described in $A A C R 2 R$ 24.13 -those containing a term that implies that the body is part of a larger entity. The EAs are generally produced at a higher level of the Forest Service hierarchy, either by the national forest itself or by the 
Forest Service or one of its regional subdivisions. The Forest Service subdivisions are established as, for example, "United States. Forest Service. Northern Region," and are also Type 1 headings. The national forests, by contrast, are entered directly as directed in $24.4 \mathrm{C3}$, nearly always qualified with the name of the state, e.g., "Nezperce National Forest (Idaho)."”

\section{THE BIBLIOGRAPHIC UTILITIES}

There are thousands of records for NEPA documents in WLN and OCLC. LC or GPO records are available for those NEPA documents that are depository items. Most of these are not cataloged by any national cataloging agency, however; but by the libraries in each region that collect the items pertaining to that region. Where a record for an item cannot be found, cataloging of newly-received NEPA documents is facilitated by records for nearly identical items that can be used as templates for new records.

Some differences of style in cataloging may lead to inconsistencies in cataloging records for these items if they come from a number of sources. The most common differences are the tagging of the title as title proper only or tagging the name of the timber sale as other title information. This might cause ambiguity or confusion in the results of "browse title" searches in some library OPACs. Another common difference among cataloging records is the presence or absence of an entry for the ranger or other person associated with the NEPA document. A search on a known personal name will probably yield some records but undoubtedly not all the NEPA documents associated with that person. A search for corporate names will also not yield all of the publications associated with a ranger district or national forest because of different judgments by different catalogers.

A more difficult problem in using records from a bibliographic utility is the different treatment of the publications associated with each timber sale. If one contributing library treats a ROD as accompanying material while another would like to catalog them as separate publications, the records cannot be freely interchanged without editing or other adjustment.

Figure 8 is an LC record for the microfiche version of a NEPA document.

Figure 9 is fuller cataloging of the paper version of the same item.
FIGURE 8. FINAL EIS: Chief Source (cover title)-LC Depository MicroficheCorporate Main Entry

Big Eightmile North Fork of Timber and Alder Creek Timber Sale

Final Environmental Impact Statement

U.S. Dept. of Agriculture, Forest Service

Salmon National Forest

Leadore Ranger District

$007 \begin{array}{llllll}\mid \text { a } & \mid \text { he-bmb024bbca043 la } & \text { |n-us-id0860 } & \text { a } & \text { |A 13.92:B 48/3/SUM.1101 } \\ \text { |anited States.|Forest Service. Leadore Ranger District. } & \end{array}$

24510 ahb |Big Eightmile, North Fork of Timber and Alder Creek timber sale|[microform] : final environmental impact statement.

260 abc [LSalmon, Idaho?] :U.S. Dept. of Agriculture, Forest Service, Salmon National

Forest, Leadore Ranger District,,$[1993]$

300 ac $\quad 33 \mathrm{p} . ; 28 \mathrm{~cm}$.

500 a |Cover title.

008 DATE $K Y=$ s DATE $1=1991 \mathrm{DATE} 2=$ PLACE $=$ idu LAN $=$ engLLUS $=$ AUDI $=\quad$ FORM $=b \quad$ CONTENTS $=$

$\mathrm{GOV} \mathrm{PUB}=\mathrm{f} \quad \mathrm{CONF}=0 \quad \mathrm{FEST}=0 \quad$ INDEX $=0 \quad \mathrm{FIC}=0 \quad \mathrm{BIOG}=$

MOD REC $=$ CAT $S=d$ RULES $=$ a CTL TYP $=$

FIGURE 9. FINAL EIS: Paper Version of Figure 8

Big Eightmile North Fork of Timber and Alder Creek Timber Sale Final Environmental Impact Statement

U.S. Dept. of Agriculture, Forest Service Salmon National Forest Leadore Ranger District

043 la |ri-us-id0860 a |A 13.92:B 48/324500|a |Big Eightmile, North Fork of

Timber and Alder Creek timber sale final environmental impact statement.260 jabc |Salmon, Idaho : USDA Forest Service, Salmon National Forest, Leadore Ranger District, 1993.

300 labc 1 v. (various pagings): :maps ; $28 \mathrm{~cm}$.

500 |a Cover title.

504 |a Includes bibliographical references.

$651-0$ a iSalmon National Forest (Idaho)

650-0 azx Forest reserves|ldahoiManagement

650-0 jaz |Logging|Idaho.

7101 jabb |United States.|Forest Service. Leadore Ranger District.

008 DATE $K Y=$ s DATE $1=1991$ DATE2 $=$ PLACE $=$ idu LAN $=$ engLLUS $=\mathbf{b}$

$\mathrm{AUDI}=\quad \mathrm{FORM}=\quad \mathrm{CONTENTS}=\quad \mathrm{GOV} \mathrm{PUB}=\mathrm{f} \quad \mathrm{CONF}=\mathbf{0} \quad \mathrm{FEST}=$

$0 \quad$ INDEX $=0 \quad$ FIC $=0 \quad$ BIOG $=$ MOD REC $-\quad$ CAT S $=\mathrm{d} \quad$ RULES $=a$ CTL 


\section{OTHER FORMATS}

While the quintessential NEPA document is one with the appearance of having been produced in the humblest and cheapest manner possible, EISs and other documents are now beginning to appear on CD-ROM. The increasing ubiquity of CD-ROM and the increasing ease with which they are produced makes this format ideal for producing NEPA documents. Producing NEPA documents in this format would solve the problem of preservation as well as making it easy to include maps and other supplementary materials. These CD-ROMs will undoubtedly have multiple documents included with a collective title on the chief source and will require a contents note and titles added entries.

Figure 10 is a cataloging record for a CD-ROM version of several NEPA documents that previously appeared in paper.

\section{FIGURE 10. CD-ROM EIS}

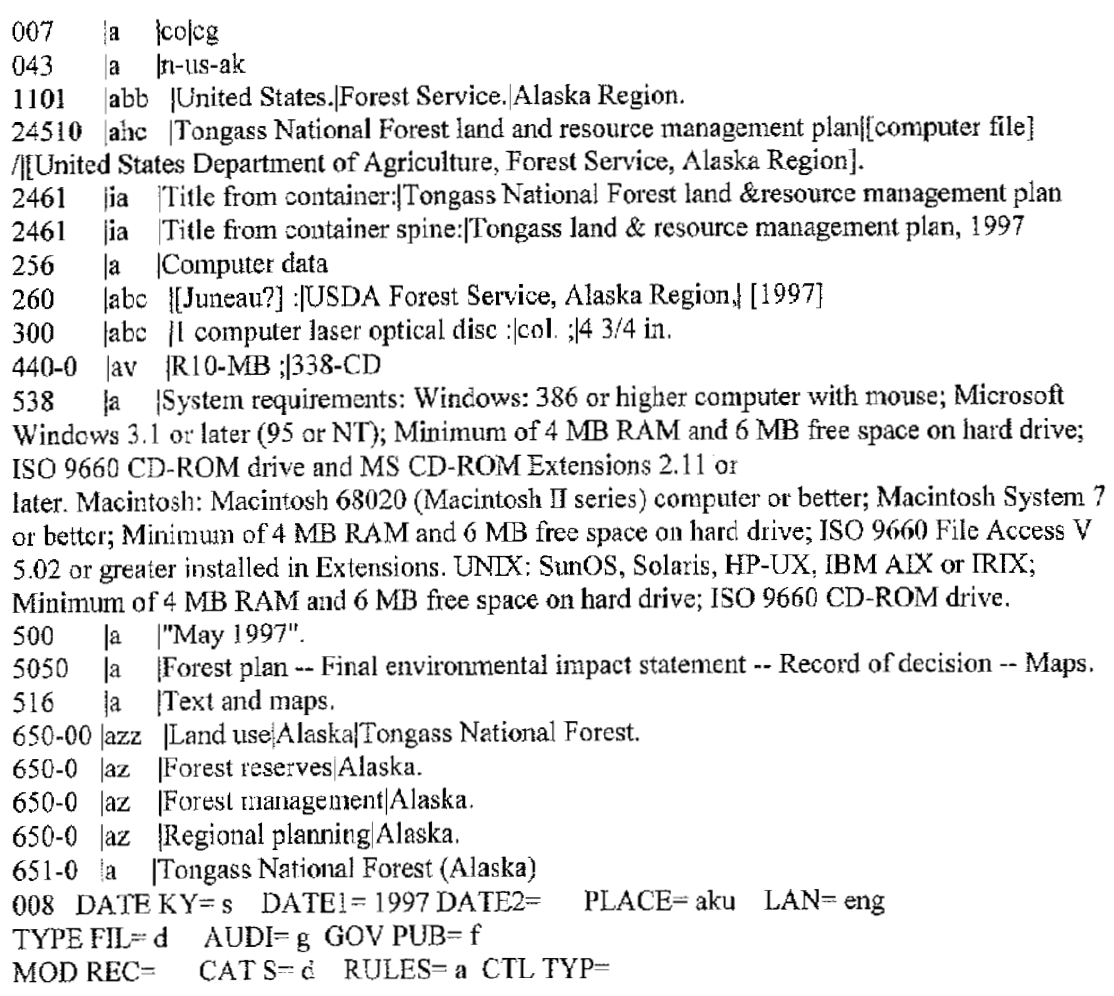

While the Internet is now a source of information about the availability of EAs, EISs, etc., they are not yet being produced as Internet documents or at least not widely or often. The Idaho Panhandle National Forests, for example, have a website that includes news releases about EISs as well as a public forum for input about them at http://www.fs.fed.us/outernet/ ipnf.catalogers should expect to see NEPA documents appearing more often as Internet or CD-ROM documents. These can be integrated into the library's catalog and collection along with everything else. This format would share many of the advantages of CD-ROM over print for these documents.

\section{CONCLUSION}

EISs and other NEPA documents are valuable sources of environmental information that are often hard to identify and acquire. Since most of them are not depository items, libraries should make an effort to collect them. They must be cataloged to make their existence known through national databases and library catalogs available on the Internet. Their cataloging should reflect the NEPA process by giving separate bibliographic identity to each NEPA document.

\section{REFERENCES}

1. See for example Cataloging Government Publications Online. (Cataloging and Classification Quarterly. 18:3/4, 1994); B. DeFelice, B. and C. Rinaldo "Crossing Subject Boundaries: Collection Management of Environmental Studies in a Multi-Library System." Library Resources \& Technical Services, 38(4):1994:333-341. Peter Hernon and Charles McClure. Public Access to Government Documents: Issues, Trends, and Strategies. Norwood, N.J.: Ablex, 1984.

2. NEPA in Action: Environmental Offices in Nineteen Federal Agencies: a Report to the Council on Environmental Quality, Executive Office of the President. Washington, D.C.: Environmental Law Institute, 1981. p.4

3. The National Environmental Policy Act: A Study of Its Effectiveness after Thenty-five Years. Washington, D.C.: Council on Environmental Quality, Executive Office of the President, 1997. p. 7.

4. See Maria Anna Jankowska and Greta de Groat. "How Green is Your Catalog? Access to Environmental Information?" Cataloging \& Classification Quarterly, 20(2):1995:105-117 and Karen Y. Stabler. "A Library Research Strategy for Locating Information on Environmental Public Policy," The Reference Librarian, 48:p. 223,1995 . 
5. P. S. Orr "Federal Environmental Impact Statements as an Important Source of Information," Governmeni Information Quarterly. 12:2 (1995):199-212. p. 207.

6. NEPA in Action, p. 17.

7. NEPA in Action, p. 18.

8. NEPA in Action, p. 32.

9. NEPA in Action, p. 39.

10. The National Environmental Policy Act:, p. 4 .

11. NEPA in Action, p. 4-5.

12. NEPA in Action, p. 5.

13. NEPA in Action, p. 5.

14. NEPA in Action, p. 36-37.

15. The National Environmental Policy Act, p. 4.

16. Joint Steering Committee for Revision of AACR. Anglo-American cataloguing rules, second edition, 1988 revision. Amendments 1993. Ottawa: Canadian Library Association; Chicago: American Library Association,1993-.

17. Anglo-American cataloguing rules, second edition, 1988 revision. Amendments 1993. p. 313.

18. The National Environmental Policy Act, p. 36-37.

19. NEPA in Action, p. 19.

20. NEPA in Action, p. 19.

21. NEPA in Action, p. 20.

22. For a list of subject headings appropriate for materials on the environment, see Greta DeGroat, "Library of Congress Subject Headings for Environmental Sources," Electronic Green Journal 7(Nov. 1997) http:/www.lib.uidaho.edu:70/ docs/egj07/groat.htm. 